\title{
Failure Causes and Improvement Strategy of Suning Commerce's Stock Option Incentive Plan
}

\author{
Jing Chen \\ Marketing Department \\ School of Business \\ Yantai Nanshan University \\ Longkou, Shandong, China 265713
}

\author{
Pinggang Guo \\ Finance and Accounting Department \\ School of Business \\ Yantai Nanshan University \\ Longkou, Shandong, China 265713
}

\begin{abstract}
With Suning Commerce as a typical research object, this paper made a systemic analysis on the stock option incentive plan of Suning Commerce and its implementation effect, to determine the failure causes of the stock option incentive plan. The failure causes mainly include three aspects: first, fixed executive price, not be adjusted with change of stock price; second, too short executive period of incentive plan and too high assessment criterion in strategy transition period of Suning Commerce; third, low correlation between stock price and company performance, so the executive period of stock option incentive plan should be extended appropriately, the executive price adjusted according to change of stock index, the stock option incentive plan reformed and other improvement made.
\end{abstract}

Keywords—stock option; incentive; vesting condition

\section{INTRODUCTION}

Stock options incentive system began in 1950s in the United States and prevailed among most American companies since 1980s. In China, it rose in 1990s, and reached a climax in 21 th century. The stock option is a right to buy a company's share at a certain price that can be exercised by incentive objects in future period based on some conditions. The exercise of the right may be affected by some conditions which are called exercise conditions. Generally speaking, exercise conditions are established by making company performance as a reference. When company performance has achieved the level established in an exercise period, the incentive objects will be eligible to buy shares at a certain price, on the contrary, when the company performance hasn't achieved the level, the incentive objects will lose the right to buy shares at the certain price. Due to close connection of incentive objects' interest with company performance and company stock market performance, there is a consistent interest between company and managements, which will reduce agent risk, supervision cost and retain talents in a certain extent. A stock option incentive system is a sword with two edges which has both of incentive and constraint functions.

\section{IMPLEMENTATION AND RESULT OF SUNING COMMERCE'S STOCK OPTION INCENTIVE PLAN}

\section{A. Stock Option Incentive Plan of Suning Commerce}

1) Incentive object: Aug 26th, 2010, Suning Appliance (now renamed Suning Commerce) announced "Suning Appliance (002024) 2010 stock options incentive plan (Draft)". The incentive objects involved in the plan were 248 backbones of Suning Commerce including company director, president, vice president, secretaries and other senior managers, core managers of headquarters, core managements of regional headquarters and region, subsidiary, and chain store shopkeeper. The company director Sun Weimin, and president Jinming got the most stock options each received 3 million stock options. Additionally, vice president, financial administrator, middle and senior manager above deputy director, part of business backbones and IT research staff above deputy manager, chain shopkeepers with good business performance also received different shares of stock options.

2) Exercise price: Suning Commerce will issue stock oriented to incentive objects such as company senior managers in a fixed time at the price of 14.5 yuan that is called exercise price. During exercise period, when the stock price of Suning Commerce is higher than 14.5 yuan, after exercising the incentive objects can gain capital from sale stock; when the price is lower than 14.5 yuan, rational incentive objects will not take exercise, because that will bring loss.

3) Exercise period: Suning Commerce stock option authorization date is November 26th, 2010. The initial time of first exercise period is November 29th, 2011, and the termination date is on November 26th, 2012. The initial time of second exercise is November 27th, 2012, and the termination date is November 26th, 2013. The starting time of third exercise period is November 27th, 2013, the end time is November 26th, 2014. The starting time of fourth exercise period is November 27th, 2014, the termination time is November 26th, 2015. The upper limit of each feasible exercise share accounts for $25 \%$ of the number of granted options. 
4) Exercise conditions: There are two performance indexes of exercise condition involved in Suning Commerce, one of which is the requirement of sale growth; another of which is the requirement of net profit growth. During four exercise periods, both of sale revenue and net profit growth are based on indexes of 2009, of which the compound growth rate of annual sale revenue should be no less than $20 \%$ compared to 2009; the compound growth rate of net profit attributed to shareholders of the company should be no less than $25 \%$ compared to 2009.

\section{B. Results of Suning Commerce Stock Option Incentive Plan}

There are two factors that determine the success of incentive plan, including whether the company performance growth meet the requirements of incentive plan, whether the stock price is above the exercise price. Only both meet the two factors, the incentive plan will be exercised.
1) The performance of Suning Commerce during 20092013: As shown in the "Table I", compared to 2009, in 2010, the compound growth rate of sale revenue is $29.51 \%$ which is more than $20 \%$ in 2009; the compound growth rate of net profit is $40.63 \%$ more than $25 \%$ of 2009 . Similarly, in 2011 , the compound growth rate of sale revenue is $26.90 \%$ which is more than $20 \%$ of 2009 ; the compound growth rate of net profit is $27.31 \%$ which is more than $25 \%$ of 2009 . However, in 2012 and 2013, the results didn't complete the performance requirement. The compound growth rate of sale revenue in 2012 and 2013 respectively is $19.05 \%$ and $15.93 \%$, both of which are less than $20 \%$ of 2009 ; the compound growth rate of net profit respectively is $-4.11 \%$ and $-42.74 \%$, both of which are $25 \%$ in 2009.

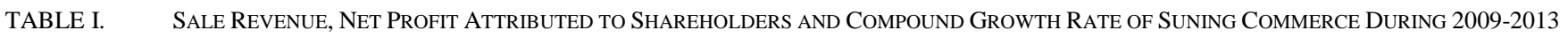

\begin{tabular}{|c|l|l|l|l|l|}
\hline Time & \multicolumn{1}{|c|}{$\mathbf{2 0 0 9}$} & $\mathbf{2 0 1 0}$ & $\mathbf{2 0 1 1}$ & $\mathbf{2 0 1 2}$ \\
\hline Index & & & & $2,515,093$ \\
\hline Net profit & $2,852,724$ & $4,011,820$ & $4,623,986$ & 306,725 \\
\hline Compound growth rate & & $40.63 \%$ & $27.31 \%$ & $-4.11 \%$ & $-42.74 \%$ \\
\hline Compound growth rate & & $75,504,739$ & $93,888,580$ & $98,357,161$ & $5,292,229$ \\
\hline
\end{tabular}

a. Note: These data come from finance reports of Suning Commerce, of which the net profit attributed to shareholders and the smaller one of before and after deduct of non-recurring profit and loss.

2) Stock price fluctuation of Suning Commerce during 2009-2013: In the first exercise period from Nov 29th, 2010 to Nov 26th, 2012, the highest stock price is 11.28 yuan which is far less than the exercise price of 14.5yuan; in the second exercise period from Nov 27th, 2012 to Nov 26th, 2013, the highest stock price is 14.33 yuan which is also less than the exercise price of 14.5 yuan. Thus, throughout 2011 to 2013 the stock price of Suning Commerce kept less than the exercise price, which made exercise meaningless.

In view of performance and stock price of Suning Commerce, although the performances in the first and second period have reached the requirement, but it made exercise nonmeaning that the stock price is all less than exercise price. In the third and fourth period, the performances have reached the requirement, which caused failure of exercise. In a word, the incentive plan is a failure.

\section{FaILURE CAUSES OF SUning COMMERCE’S STOCK OPTION INCENTIVE PLAN}

\section{A. Fixed Exercise Price Lack of Adjustment with Stock Price}

The exercise price of 14.5 yuan is fixed, can't be changed until special conditions which include the conditions directly or possibly related to company share capital and distribution of cash dividends, etc., and exclude fluctuation of stock price. Suning Commerce stock option incentive plan has 4 exercise periods in 5 years, in view of operating performance, although the performance of former two periods have reached requirements of the incentive plan, due to the higher exercise price than stock price, exercise came failure and lost realistic significance. If the exercise price can be changed with fluctuation of stock market price, the exercise of former two can be carried out smoothly. But from the point of provisions of CSRC, the exercise price adjustment is not realistic.

\section{B. Too Short Exercise Periods of the Incentive Plan, Too High Assessment Criterion in Strategy Transition Period of Suning Commerce}

The exercise period of Suning Commerce's stock option incentive plan is within strategy transition period of Suning Commerce with a characteristic of high input and low revenue. The incentive plan set a growth rate of performance which was too high and wasn't suitable to the strategy transition. In this period, it was a big challenge for senior managers both completing strategy transition and keeping performance growth.

In order to catch up with the development of e-commerce, Suning Commerce invested a large number capital in online shop. In 2012, Suning Commerce carried out these measures in e-commerce: firstly establishing a top e-commerce headquarter; secondly building the logistics system which has cost 20 billion yuan; thirdly merger "redbaby". Additionally, in order to improve sale and brand and core competitiveness, Suning Commerce has invested a large number of promotion expenses. At same time, Suning Commerce has cost a larger amount of human resource, material resource, finance to establish Suning E-commerce. However, these invests couldn't be recovered, the profit from Suning E-commerce couldn't be shown in short time of the incentive plan.

For construction of offline store, the following strategies are used: the company adjust or shut down many adverse operating stores in every year; new stores establish in good 
regions. Such strategies play a positive role in promoting the long-term development of company, but may have a negative impact on short-term performance.

Suning Commerce set the exercise conditions without fully considering the strategic transition period, of which the performance requirements were too rigor to achieve regardless how hard senior managers made.

\section{The Stock Price Can't Accurately Reflect the Performance}

A perfect security market plays an important role in success or failure of stock option incentive system. In China, securities market started in 1990s, has been 24 years, and is still in developing stage. Compared to western developed capital market, China securities market is still far from mature, and can't provide the necessary environmental basis for stock option incentive system.

Since the stock market is in a developing period, the stock price is not always fully synchronized to reflect company performance, development capacity and financial condition, and is affected by many factors, such as investor expectations, subject matter, economic policy, the tendency of entire plate and others. In 2010 and 2011, the compound growth rate achieved the expected goal, but the price is far lower than 14.50 yuan, which leads to exercise failure of incentive objects.

\section{IMPROVE STRATEGIES OF SUNING COMMERCE's STOCK OPTION INCENTIVE PLAN}

\section{A. Appropriately Relax the Exercise Period of Stock Option Incentive Plan}

The exercise period of Suning Commerce is 5 years which obviously cannot realize incentive management objectives. Because in $\mathrm{Su}$ ningyun transition period a large number of investment capital is required which can't recover in a short term, the performance improvement brought by strategic transition will not appear in a short term. Obviously, at this point it is unfair to assess management. In order to achieve long-term incentive, from the point of fairness to management, the exercise period should be appropriately relaxed. Similarly with the United States, it should be relaxed to 10 years when the transition has completed with normal performance.

\section{B. Improve Relevant Laws and Regulations, Allow Exercise Price Adjustment with Fluctuation of Stock Price}

Since a single stock can't resist systematic risks, during stock market downturn, the performance rise of Suning Commerce played a limited role on stock price. Therefore, a fixed exercise price doesn't clearly play a role of incentive, which is also unfair for incentive objects. In this case, should allow that the exercise price is adjusted with changes of and comprehensive index, because generally the fluctuation of stock price can reflect overall impacts of systematic risks. After adjusted, the exercise price has eliminated systematic risks, and can ensure fairness and effectiveness of stock option incentive measures.

\section{Reform of Stock Option Incentive Plan}

In order to keep talents and motivate executives, Suning Commerce should take reform of the stock option incentive plan which means taking "base shares plus extra incentive shares" as incentive measures. Namely, when company performance achieves the goal, the incentive objects can take exercise at a price of lower than market price in a certain ratio, at the moment, due to a low upper limit of exercise price, this part of reward is guaranteed stock awards. In addition, the stock price reach above the exercise price, executives can purchase another part of incentive stock to achieve a full exercise. Thus, for executives, as long as promotion of company performance, they will get guaranteed incentive stock. At the same time when promote performance, the stock price also rose to realize overall exercise. The measure of "base shares plus extra incentive shares" can improve positivity of executives to improve company performance, and achieve full exercise.

\section{CONCLUSION}

This paper made analysis on the specific indicators of the stock option incentive plan of Suning Commerce, and further put forward the implementation results of the third stock option incentive plan of Suning Commerce. The desired implementation result is not achieved for this stock option incentive plan, so this paper further analyzed the reasons for the failure of the company, and the main conclusions are as follows:

- Chinese stock market is not yet mature, so the analysis on the success and failure of the company's stock option incentive plan has a certain significance of reference for Suning Commerce and other companies.

- Suning Commerce's failure in equity incentive can be attributed primarily to the following reasons: fixed executive price, not be adjusted with change of stock price; too short executive period of incentive plan and too high assessment criterion in strategy transition period of Suning Commerce; no accurate reflection of stock price on the company's operating performance.

- The executive period of stock option incentive plan can be extended appropriately, the relevant laws and regulations completed, the executive price adjusted according to change of stock index and other improvement made.

\section{REFERENCES}

[1] Li Yan. Research on Share Incentive Mechanism of Operators of China's Listed Company [D]. CNKI, 008.10.1.

[2] Feng Jiaxue. Suning E-commerce Recreated from Suning in 10 Years—"Second Chain of Suning" [J]. China New Time, 2011.11.15.

[3] Fu Hui. Study on Stock Option Incentive Problems of China's Listed Company [J]. Special Zone Economy, 2011.2.15.

[4] Chen Hua. Suning Promotes the Largest Equity Incentive within the Industry [N]. Oriental Morning Post, 2010.8.26.

[5] Xu Yanqiu. Study on Validation of Share Incentive Mechanism of China's Listed Company [D]. CNKI, 2011.4.1. 
[6] Kang Gengling. Suning E-commerce Invests 1 Billion to Build up Top E-commerce Headquarters in Nanjing [J]. Household Appliances, 2012.5.1. 